\title{
The EULAR points to consider for use of antirheumatic drugs before pregnancy, and during pregnancy and lactation
}

\author{
Carina Götestam Skorpen, ${ }^{1,2,3}$ Maria Hoeltzenbein, ${ }^{4}$ Angela Tincani, ${ }^{5}$ \\ Rebecca Fischer-Betz, ${ }^{6}$ Elisabeth Elefant, ${ }^{7}$ Christina Chambers, ${ }^{8}$ Josè da Silva ${ }_{1}^{9}$ \\ Catherine Nelson-Piercy, ${ }^{10}$ Irene Cetin, ${ }^{11}$ Nathalie Costedoat-Chalumeau, ${ }^{12,13}$ \\ Radboud Dolhain, ${ }^{14}$ Frauke Förger, ${ }_{1}^{15}$ Munther Khamashta, ${ }^{16}$ \\ Guillermo Ruiz-Irastorza, ${ }^{17}$ Angela Zink, ${ }^{18}$ Jiri Vencovsky, ${ }^{19}$ Maurizio Cutolo, ${ }^{20}$ \\ Nele Caeyers, ${ }^{21}$ Claudia Zumbühl, ${ }^{22}$ Monika Østensen ${ }^{1,2}$
}

\begin{abstract}
Handling editor Tore K Kvien
- Additional material is published online only. To view please visit the journal online (http://dx.doi.org/10.1136/ annrheumdis-2015-208840).
\end{abstract}

For numbered affiliations see end of article.

\section{Correspondence to} Professor Monika Østensen, National Service for Pregnancy and Rheumatic Diseases, Department of Rheumatology, Trondheim University Hospital, Trondheim 7006, Norway: monika.ostensen@gmail.com

Received 30 October 2015 Revised 21 December 2015 Accepted 22 January 2016 Published Online First 17 February 2016

\section{ABSTRACT}

A European League Against Rheumatism (EULAR) task force was established to define points to consider on use of antirheumatic drugs before pregnancy, and during pregnancy and lactation. Based on a systematic literature review and pregnancy exposure data from several registries, statements on the compatibility of antirheumatic drugs during pregnancy and lactation were developed. The level of agreement among experts in regard to statements and propositions of use in clinical practice was established by Delphi voting. The task force defined 4 overarching principles and 11 points to consider for use of antirheumatic drugs during pregnancy and lactation. Compatibility with pregnancy and lactation was found for antimalarials, sulfasalazine, azathioprine, ciclosporin, tacrolimus, colchicine, intravenous immunoglobulin and glucocorticoids. Methotrexate, mycophenolate mofetil and cyclophosphamide require discontinuation before conception due to proven teratogenicity. Insufficient documentation in regard to fetal safety implies the discontinuation of leflunomide, tofacitinib as well as abatacept, rituximab, belimumab, tocilizumab, ustekinumab and anakinra before a planned pregnancy. Among biologics tumour necrosis factor inhibitors are best studied and appear reasonably safe with first and second trimester use. Restrictions in use apply for the few proven teratogenic drugs and the large proportion of medications for which insufficient safety data for the fetus/child are available. Effective drug treatment of active inflammatory rheumatic disease is possible with reasonable safety for the fetus/child during pregnancy and lactation. The dissemination of the data to health professionals and patients as well as their

implementation into clinical practice may help to improve the management of pregnant and lactating patients with rheumatic disease.

\section{INTRODUCTION}

CrossMark

To cite: Götestam

Skorpen C, Hoeltzenbein M, Tincani $A$, et al. Ann Rheum Dis 2016;75:795-810.

ability most women with inflammatory rheumatic diseases (RDs) can contemplate pregnancy though substantial risk for adverse maternal and fetal outcomes remain particularly in $\mathrm{RD}$ with organ involvement. Drug treatment during pregnancy disease which itself can be a threat for fetal well-being and pregnancy outcome. The risk of leaving active inflammatory RD of the mother untreated for 9 months must be weighed against any potential harm through drug exposure of the fetus.

Adjustment of therapy in a patient planning a pregnancy aims to use medications that support disease control in the mother and are considered safe for the fetus. However, only a limited number of antirheumatic/immunosuppressive drugs fulfil these requirements. With the rapidly increasing number of medications available for the treatment of $\mathrm{RD}$, knowledge on safety in pregnancy lags behind. A consensus paper on use of antirheumatic drugs in pregnancy and lactation was published in $2006^{1}$ with an update on immunosuppressive drugs in 2008. ${ }^{2}$ A European League Against Rheumatism (EULAR) task force regarded it timely to collect new available data from the literature and from several databases, and reach expert consensus on their compatibility during pregnancy and lactation, resulting in EULAR points to consider for use of antirheumatic drugs before pregnancy and during pregnancy and lactation.

\section{PARTICIPANTS AND METHODS}

The EULAR task force on antirheumatic drugs during pregnancy and lactation is a multidisciplinary committee consisting of 20 members from 10 European countries and the USA ( 9 rheumatologists, 3 internists, 1 obstetrician, 2 rheumatologist/ epidemiologists, 1 specialist in Obstetric Medicine, 1 geneticist, 2 patients with RD as patients' representatives and 1 research fellow). The objective was to formulate points to consider for the use of antirheumatic drugs during pregnancy and lactation by identifying and critically evaluating recent literature and registry data. The task force followed the procedures outlined in $2004^{3}$ and updated in 2014.4 may be required in order to control maternal

\section{Systematic literature review}

At the first meeting, the committee decided on the medications to be included in the systematic literature review (SLR): Non-steroidal anti-inflammatory drugs (NSAIDs), glucocorticoids, conventional 
synthetic DMARDs: methotrexate (MTX), cyclophosphamide, sulfasalazine, leflunomide, antimalarials, azathioprine, colchicine, ciclosporin, tacrolimus, mycophenolate mofetil (MMF), intravenous immunoglobulin (IVIG) and targeted synthetic DMARDs: tofacitinib. Biologic DMARDs included were tumour necrosis factor inhibitors (TNFi) (adalimumab, certolizumab pegol, etanercept, golimumab and infliximab), the T cell costimulation inhibitor abatacept, the anti-B cell agents rituximab and belimumab, the interleukin (IL)- 6 receptor-blocking monoclonal antibody tocilizumab, and the IL-1 receptor antagonist anakinra. Biosimilars were not included due to lack of data. Two electronic searches, one for biologic drugs and a separate search for non-biologic drugs were performed in Embase, Medline, PubMed and Cochrane Library from 1 January 2008 to 1 April 2015 by a research librarian at the Norwegian University of Science and Technology University library; Medicine and Health Library, drawing on the Cochrane Musculoskeletal group's strategy for searching for all RDs and adjusting the strategy to make use of the various database search facilities. ${ }^{5}$ The searches were restricted to effects in pregnancy and/or perinatal effects, and excluded reviews (for details see online supplementary figure S1). References of articles found were screened for additional evidence. The search period of 2008-2015 was chosen because inclusion of publications in the consensus paper of 2006 ended early in 2006, and the update of 2008 ended in 2007. As the update publication ${ }^{2}$ did not include all non-biologic drugs, an additional search for the period 2006-2008 was performed for 10 drugs; NSAIDs, glucocorticoids, MTX, cyclophosphamide, sulfasalazine, antimalarials, azathioprine, colchicine, ciclosporin and IVIGs. Because of paucity of lactation data, all reports on lactation exposures to antirheumatic drugs published 19702015 derived from LactMed, a database in the Toxicology Data Network, were included.

Publications were restricted to the English language and included prospective and retrospective studies, cohort studies, case-control studies, and case reports. In addition abstracts from major international congresses were included. The search was not limited to $\mathrm{RD}$, but all indications for a given drug were included (see online supplementary figure S1). Results of the different databases were combined and duplicates were excluded; issues regarding inclusion or exclusion of articles were resolved by discussion and consensus between the fellow (CGS) and convenor (MØ).

\section{Registries}

The task force obtained access to pregnancy reports from two pharmacovigilance centres and four safety databases from pharmaceutical industries (see online supplementary table S1), and extracted data for all pregnancies with known outcomes.

\section{Data collection sheet}

A data collection sheet was constructed to extract relevant data on exposure during pregnancy and lactation. Included were patient characteristics, drug dosing, and exposure time before and during pregnancy/lactation, concomitant medication, and occurrence of pregnancy complications (miscarriages and elective terminations, stillbirth, and preterm delivery) or adverse child outcomes. Congenital malformations, birth weight, neonatal health, infections during the 1st year of life, vaccination responses, and follow-up of childrens' physical and neurocognitive development were also recorded. Reports that did not disclose the outcome of pregnancy or those for which the temporal association between drug exposure and onset of pregnancy could not be determined were excluded from analysis.
Likewise, incomplete reports on breastfeeding exposures were excluded.

\section{Predefined outcomes}

We defined as the primary outcome major congenital malformations in live-born children or aborted fetuses. The only secondary outcome included was miscarriages up to 20 weeks gestation. Other outcomes like termination of pregnancy, preeclampsia, prematurity, low birth weight, perinatal and postnatal problems were either incompletely documented or imprecise because of confounding factors. For lactation exposure the primary child outcome was defined as any adverse effect (clinical or laboratory).

\section{Experts' consensus and Delphi rounds}

The results of the SLR were presented to the task force members to initiate group discussions and to arrive at statements for the use of antirheumatic drugs in pregnancy and lactation. Statements were based on the consensus papers of 2006/2008 ${ }^{12}$ with added evidence from the new SLR as well as unpublished registry data. In the formulation of statements, emphasis was put on congenital malformations since this was the primary outcome that was consistently reported in all publications included. Given the paucity of high quality data and subjective nature of many decisions, the task force agreed that the practicing clinician would be better served by having each expert stating (dis)agreement with the proposed statement and expressing their practice regarding the use of each medication in daily practice (see online supplementary table S2). The Delphi technique ${ }^{6}$ was used to reach consensus on the statements and rate of agreement for the propositions for clinical use.

\section{Strength of evidence}

The classical ranking of evidence scores defines systematic reviews of randomised controlled trials (RCTs) as providing the highest level of evidence, followed by individual $\mathrm{RCT}^{7}$ Classical scores of evidence focus on efficacy of an intervention or of drugs, but not on safety. By contrast, evaluation of drugs in pregnancy and lactation has its focus on safety for the embryo/ fetus or child, not on efficacy. No adequate ranking system for evaluating strength of evidence (SOE) in regard to safety of drugs in pregnancy and lactation has been developed. After several rounds of discussion, the group decided to use two classical ranking systems in spite of their shortcomings in regard to reproduction issues.

The quality of evidence based on study design was rated according to the Grading of Recommendations Assessment, Development and Evaluation (GRADE) system and Oxford Centre of Evidence Rating. ${ }^{9}$ Data from SLR and data added from registries were subjected to group discussion to establish SOE regarding the statements. For each statement, SOE was graded using a 1-4 ordinal scale for GRADE (see online supplementary table S3) and a 1-5 ordinal scale for Oxford (see online supplementary table S4). The members were then asked to select the proposition that best described their personal current use of each drug during pregnancy and lactation, as described above (see online supplementary table S2). The percentage of consensus for the statements, and agreement for clinical use in pregnancy and lactation were calculated.

\section{RESULTS}

In the first meeting the task force defined four overarching principles. In the following two meetings and seven online Delphi 
rounds (four concerning medication in pregnancy and three concerning medication during lactation) 11 points to consider were developed (table 1).

\section{Result of SLR}

The electronic searches identified a total of 5960 references on antirheumatic drugs during pregnancy and lactation. Additional references were added from hand searches. Nine hundred and forty-four duplicates were excluded (see online supplementary figure S1). A total of 319 publications were eligible for analysis: 45 cohort studies (including 7 abstracts), 24 case-control studies (including 1 abstract) and 250 case series/case reports (including 21 abstracts). Unpublished data from six registries were also included (see online supplementary table S1).

Type of studies recorded, references on cohorts and case controls, number of pregnancies included, pregnancy outcomes, and SOE for each drug or group of drugs are presented in table 2. References on case reports and case series are available in online supplementary table S5.

\section{General aspects of SLR}

\section{Adverse pregnancy outcomes}

Adverse outcomes other than congenital malformations were not consistently reported; this also applies to miscarriages. Rates of miscarriages may be imprecise since they depend on the time point at which a pregnant patient is included in a study. Only MTX and MMF have been consistently shown to increase the rate of miscarriages. Combination therapies with MTX have sometimes also increased the rate of miscarriages (example table 2, abatacept). The observed correlation between NSAIDs and miscarriage in some studies is controversial because of several confounding factors, including confounding by indication, that often have not been addressed in the studies. The majority of data relate to first trimester exposure. Exposures in the second and third trimesters have been reported for medications either regarded as compatible with pregnancy (examples glucocorticoids, azathioprine, antimalarials) or when serious maternal disease requires therapy in pregnancy (example cyclophosphamide). Drug exposures before conception were included for

\section{Table 1 The EULAR points to consider for use of antirheumatic drugs before pregnancy and during pregnancy and lactation}

Overarching principles

A Family planning should be addressed in each patient of reproductive age and adjustment of therapy considered before a planned pregnancy.

B Treatment of patients with rheumatic disease before/during pregnancy and lactation should aim to prevent or suppress disease activity in the mother and expose the fetus/ child to no harm.

C The risk of drug therapy for the child should be weighed against the risk that untreated maternal disease represents for the patient and the fetus or child.

D The decision on drug therapy during pregnancy and lactation should be based on agreement between the internist/rheumatologist, gynaecologist/obstetrician and the patient, and including other healthcare providers when appropriate.

Points to consider for use of antirheumatic drugs in pregnancy*

Grade of recommendationt

1 csDMARDs proven compatible with pregnancy are hydroxychloroquine, chloroquine, sulfasalazine, azathioprine, ciclosporin, tacrolimus and B colchicine. They should be continued in pregnancy for maintenance of remission or treatment of a disease flare.

2 csDMARDs‡ methotrexate, mycophenolate mofetil and cyclophosphamide are teratogenic and should be withdrawn before pregnancy. B

3 Non-selective COX inhibitors (non-steroidal anti-inflammatory drugs, NSAIDs) and prednisone should be considered for use in pregnancy if needed to B control active disease symptoms. NSAIDs should be restricted to the first and second trimesters.

4 In severe, refractory maternal disease during pregnancy methylprednisolone pulses, intravenous immunoglobulin or even second or third trimester use D of cyclophosphamide should be considered.

5 csDMARDsł, tsDMARDs§ and anti-inflammatory drugs with insufficient documentation concerning use in pregnancy should be avoided until further B-D evidence is available. This applies to leflunomide, mepacrine, tofacitinib and selective COX II inhibitors.

6 Among bDMARDs continuation of tumour necrosis factor (TNF) inhibitors during the first part of pregnancy should be considered. Etanercept and certolizumab may be considered for use throughout pregnancy due to low rate of transplacental passage.

7 bDMARDs $\uparrow$ rituximab, anakinra, tocilizumab, abatacept, belimumab and ustekinumab have limited documentation on safe use in pregnancy and should be replaced before conception by other medication. They should be used during pregnancy only when no other pregnancy-compatible drug can effectively control maternal disease.

Points to consider for use of antirheumatic drugs during lactation*

rade of recommendationt

1 csDMARDs $\ddagger$ and anti-inflammatory drugs compatible with breast feeding should be considered for continuation during lactation provided the child does not have conditions that contraindicate it. This applies to hydoxychloroquine, chloroquine, sulfasalazine, azathioprine, ciclosporin, tacrolimus, colchicine, prednisone, immunoglobulin, non-selective COX inhibitors and celecoxib.

2 csDMARDs $\neq$, tsDMARDs§ and anti-inflammatory drugs with no or limited data on breast feeding should be avoided in lactating women. This applies to methotrexate, mycophenolate mofetil, cyclophosphamide, leflunomide, tofacitinib and cyclooxygenase II inhibitors other than celecoxib.

3 Low transfer to breast milk has been shown for infliximab, adalimumab, etanercept and certolizumab. Continuation of TNF inhibitors should be considered compatible with breast feeding.

4 bDMARDs 9 with no data on breast feeding such as rituximab, anakinra, belimumab, ustekinumab, tocilizumab and abatacept should be avoided during lactation if other therapy is available to control the disease. Based on pharmacological properties of bDMARDs $\uparrow$, lactation should not be discouraged when using these agents, if no other options are available.

* Level of evidence is given for each drug separately in table 2 .

tA Category I evidence from meta-analysis of randomised controlled trials (1A) or from at least one randomised controlled trial (1B)

B Category II evidence from at least one controlled study without randomisation (2A) or from at least one type of quasi-experimental study (2B), or extrapolated recommendations from category I evidence.

C Category III evidence from descriptive studies, such as comparative studies, correlation studies or case-control studies (3), or extrapolated recommendation from category I or II evidence. D Category IV evidence from expert committee reports or opinions and/or clinical experience of respected authorities (4), or extrapolated recommendation from category II or III evidence. ${ }^{10}$

¥Conventional synthetic DMARDs.

§Targeted synthetic DMARDs.

ПBiologic DMARDs.

Götestam Skorpen C, et al. Ann Rheum Dis 2016;75:795-810. doi:10.1136/annrheumdis-2015-208840 
Table 2 Characteristics of studies and outcome of pregnancy exposure related to medications used to treat rheumatic diseases, SLR-period 2008-2015*

\begin{tabular}{|c|c|c|c|c|c|c|c|c|}
\hline \multirow{2}{*}{$\begin{array}{l}\text { Drug } \\
\text { Non-selective COX } \\
\text { inhibitors } \\
\text { (classical NSAIDs) }\end{array}$} & \multirow{2}{*}{$\begin{array}{l}\text { Type of publication } \\
\text { in numbers } \\
3 \text { cohorts } \\
3 \text { case controls }\end{array}$} & \multirow{2}{*}{$\begin{array}{l}\text { References } \\
\text { on cohorts } \\
\text { and case } \\
\text { controls } \\
11-16\end{array}$} & \multirow{2}{*}{$\begin{array}{l}\begin{array}{l}\text { Total } \\
\text { pregnanciest } \\
\text { (prospective/ } \\
\text { retrospective) }\end{array} \\
17992 \\
\text { (7684/10 308) }\end{array}$} & \multirow{2}{*}{ 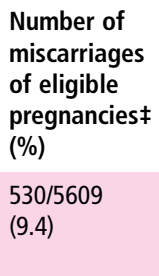 } & \multirow{2}{*}{$\begin{array}{l}\text { Number of } \\
\text { congenital } \\
\text { malformations } \\
\text { of live births§ } \\
\text { (\%) } \\
457 / 12354 \\
(3.7)\end{array}$} & \multirow{2}{*}{$\begin{array}{l}\text { Comments on miscarriages } \\
\text { (MC) and/or congenital } \\
\text { malformations (CM) compared } \\
\text { with control groups and/or } \\
\text { background data§ } \\
\text { No difference MC or CM }\end{array}$} & \multicolumn{2}{|c|}{$\begin{array}{l}\text { Strength of } \\
\text { evidence } \\
\text { according to } \\
\text { GRADE Oxford }\end{array}$} \\
\hline & & & & & & & ++++ & $2 a$ \\
\hline $\begin{array}{l}\text { Glucocorticoids } \\
\text { (any route/ } \\
\text { formulation) }\end{array}$ & $\begin{array}{l}2 \text { cohorts } \\
5 \text { case controls } \\
17 \text { case reports/series } \\
(1 \text { abstract) }\end{array}$ & $1618-23$ & $\begin{array}{l}35009 \\
(94 / 3406)\end{array}$ & $\begin{array}{l}70 / 331 \\
(21.1)\end{array}$ & $\begin{array}{l}34 / 3180 \\
(1.1)\end{array}$ & $\begin{array}{l}\text { MC slightly increased } \\
\text { confounded by disease } \\
\text { indication, no difference CM } \\
\text { compared with control groups }\end{array}$ & +++ & $2 b$ \\
\hline Antimalarials & $\begin{array}{l}2 \text { cohorts } \\
4 \text { case controls }\end{array}$ & $1624-28$ & $\begin{array}{l}492 \\
(170 / 322)\end{array}$ & $\begin{array}{l}20 / 170 \\
(11.8)\end{array}$ & $\begin{array}{l}23 / 492 \\
(4.7)\end{array}$ & No difference $\mathrm{MC}$ or $\mathrm{CM}$ & ++++ & $2 \mathrm{a}$ \\
\hline Azathioprine & $\begin{array}{l}4 \text { cohorts } \\
\text { (1 abstract) } \\
7 \text { case controls } \\
7 \text { case reports/series } \\
\text { (1 abstract) }\end{array}$ & $163134-42$ & $\begin{array}{l}1327 \\
(434 / 893)\end{array}$ & $\begin{array}{l}40 / 559 \\
(7.2)\end{array}$ & $\begin{array}{l}65 / 1327 \\
(4.9)\end{array}$ & $\begin{array}{l}\text { No significant difference MC or } \\
\text { CM compared with } \\
\text { disease-matched controls }\end{array}$ & ++++ & $2 a$ \\
\hline Methotrexate & $\begin{array}{l}2 \text { cohorts } \\
2 \text { case controls } \\
8 \text { case reports/series }\end{array}$ & 16274344 & $\begin{array}{l}372 \\
(332 / 40)\end{array}$ & $\begin{array}{l}140 / 329 \\
(42.6)\end{array}$ & $\begin{array}{l}15 / 143 \\
(10.5)\end{array}$ & $\begin{array}{l}\text { Increased rate MC } \\
\text { Increased rate CM with specific } \\
\text { pattern }\end{array}$ & ++++ & $2 b$ \\
\hline Cyclophosphamide & $\begin{array}{l}2 \text { cohorts } \\
28 \text { case reports/series } \\
\text { (2 abstracts) }\end{array}$ & 4546 & $\begin{array}{l}276 \\
(160 / 116)\end{array}$ & $\begin{array}{l}\text { No separate } \\
\text { studies on MC } \\
\text { published }\end{array}$ & $\begin{array}{l}23 / 86 \\
(26.7)\end{array}$ & $\begin{array}{l}\text { High rate CM No studies with } \\
\text { control group available }\end{array}$ & +++ & $2 b$ \\
\hline $\begin{array}{l}\text { Mycophenolate } \\
\text { mofetil }\end{array}$ & $\begin{array}{l}2 \text { cohorts } \\
1 \text { register data } \\
20 \text { case reports/series } \\
\text { (2 abstracts) }\end{array}$ & 4750 & $\begin{array}{l}333 \\
(199 / 134)\end{array}$ & $\begin{array}{l}119 / 318 \\
(37.4)\end{array}$ & $\begin{array}{l}48 / 174^{* *} \\
(27.6)\end{array}$ & $\begin{array}{l}\text { In studies without control group } \\
\text { high rate } \mathrm{MC} \text { and } \mathrm{CM} \text { with } \\
\text { specific pattern }\end{array}$ & +++ & $2 b$ \\
\hline Colchicine & $\begin{array}{l}1 \text { cohort } \\
1 \text { case control } \\
1 \text { case series }\end{array}$ & 5152 & $\begin{array}{l}460 \\
(238 / 222)\end{array}$ & $\begin{array}{l}30 / 417 \\
(7.2)\end{array}$ & $\begin{array}{l}11 / 460 \\
(2.4)\end{array}$ & No difference $\mathrm{MC}$ or $\mathrm{CM}$ & +++ & $2 b$ \\
\hline IVIG & $\begin{array}{l}3 \text { cohorts } \\
3 \text { case reports/series }\end{array}$ & $53-55$ & $\begin{array}{l}96 \\
(93 / 3)\end{array}$ & $\begin{array}{l}24 / 93 \\
(25.8)\end{array}$ & $0 / 96$ & $\begin{array}{l}\text { No increase of MC or } \mathrm{CM} \\
\text { compared with disease-matched } \\
\text { controls }\end{array}$ & ++ & $3 b$ \\
\hline Tofacitinib & $\begin{array}{l}1 \text { case series } \\
\text { (abstract) }\end{array}$ & - & $\begin{array}{l}27 \\
(27 / 0)\end{array}$ & $\begin{array}{l}7 / 27 \\
(25.9)\end{array}$ & $1 / 15$ & $\begin{array}{l}\text { In case series and with } \\
\text { concomitant MTX exposure high } \\
\text { rate MC, no indication of an } \\
\text { increased rate CM }\end{array}$ & + & 4 \\
\hline Infliximab & $\begin{array}{l}9 \text { cohorts } \\
\text { (1 abstract) } \\
4 \text { case controls } \\
\text { (1 abstract) } \\
2 \text { register data } \\
\text { (1 abstract) } \\
16 \text { case reports/series } \\
(3 \text { abstracts) }\end{array}$ & $273656-66$ & $\begin{array}{l}1161 \\
(968 / 193)\end{array}$ & $\begin{array}{l}64 / 676 \\
(9.5)\end{array}$ & $\begin{array}{l}20 / 756 t \dagger \\
(2.6)\end{array}$ & No difference $\mathrm{MC}$ or $\mathrm{CM}$ & ++++ & $2 b$ \\
\hline
\end{tabular}


Table 2 Continued

\begin{tabular}{|c|c|c|c|c|c|c|c|c|}
\hline \multirow{2}{*}{$\begin{array}{l}\text { Drug } \\
\text { Adalimumab }\end{array}$} & \multirow{2}{*}{$\begin{array}{l}\text { Type of publication } \\
\text { in numbers } \\
10 \text { cohorts } \\
\text { ( } 2 \text { abstracts) } \\
5 \text { case controls } \\
\text { (1 abstract) } \\
2 \text { register data } \\
\text { (1 abstract) } \\
6 \text { case reports/series } \\
\text { (1 abstract) }\end{array}$} & \multirow{2}{*}{$\begin{array}{l}\text { References } \\
\text { on cohorts } \\
\text { and case } \\
\text { controls } \\
162736 \\
56-5860-68\end{array}$} & \multirow{2}{*}{$\begin{array}{l}\text { Total } \\
\text { pregnanciest } \\
\text { (prospective/ } \\
\text { retrospective) }\end{array}$} & \multirow{2}{*}{$\begin{array}{l}\begin{array}{l}\text { Number of } \\
\text { miscarriages } \\
\text { of eligible } \\
\text { pregnancies } \\
(\%)\end{array} \\
23 / 191 \\
(12.0)\end{array}$} & \multirow{2}{*}{$\begin{array}{l}\text { Number of } \\
\text { congenital } \\
\text { malformations } \\
\text { of live births§ } \\
(\%) \\
24 / 350+\dagger \\
(6.9)\end{array}$} & \multirow{2}{*}{$\begin{array}{l}\text { Comments on miscarriages } \\
\text { (MC) and/or congenital } \\
\text { malformations (CM) compared } \\
\text { with control groups and/or } \\
\text { background data§ } \\
\text { No significant difference MC } \\
\text { Increased rate CM in one study, } \\
\text { no increase compared with } \\
\text { disease-matched controls }\end{array}$} & \multicolumn{2}{|c|}{$\begin{array}{l}\text { Strength of } \\
\text { evidence } \\
\text { according to } \\
\text { GRADE Oxford }\end{array}$} \\
\hline & & & & & & & +++ & $2 b$ \\
\hline Etanercept & $\begin{array}{l}3 \text { cohorts } \\
3 \text { case controls } \\
\text { (1 abstract) } \\
2 \text { register data } \\
\text { (1 abstract) } \\
11 \text { case } \\
\text { reports/series } \\
\text { (3 abstracts) }\end{array}$ & $\begin{array}{l}16275758 \\
6465\end{array}$ & $\begin{array}{l}332 \\
(213 / 119)\end{array}$ & $\begin{array}{l}12 / 74 \\
(16.2)\end{array}$ & $\begin{array}{l}9 / 251+\dagger \\
(3.6)\end{array}$ & No difference $\mathrm{MC}$ or $\mathrm{CM}$ & +++ & $2 \mathrm{~b}$ \\
\hline Certolizumab & $\begin{array}{l}2 \text { cohorts } \\
1 \text { case control } \\
2 \text { case reports/series }\end{array}$ & 616365 & $\begin{array}{l}362 \\
(243 / 119)\end{array}$ & $\begin{array}{l}52 / 339 \\
(15.3)\end{array}$ & $\begin{array}{l}12 / 267+\dagger \\
(4.5)\end{array}$ & $\begin{array}{l}\text { No increased rate MC or CM No } \\
\text { studies with control group } \\
\text { available }\end{array}$ & ++ & $3 b$ \\
\hline Golimumab & $\begin{array}{l}1 \text { cohort } \\
1 \text { case series } \\
\text { (abstract) }\end{array}$ & 65 & $\begin{array}{l}50 \\
(38 / 12)\end{array}$ & $\begin{array}{l}13 / 47 \\
(27.7)\end{array}$ & $0 / 26 t \dagger$ & $\begin{array}{l}\text { With concomitant MTX exposure } \\
\text { high rate MC, no indication of an } \\
\text { increased rate CMNo studies } \\
\text { with control group available }\end{array}$ & + & 4 \\
\hline $\begin{array}{l}\text { All TNF inhibitors, } \\
\text { including studies not } \\
\text { differentiating } \\
\text { between them }\end{array}$ & $\begin{array}{l}10 \text { cohorts } \\
\text { ( } 3 \text { abstracts) } \\
5 \text { case controls } \\
\text { (1 abstract) } \\
2 \text { register data } \\
\text { (1 abstract) } \\
32 \text { case reports/series } \\
\text { (7 abstracts) }\end{array}$ & $\begin{array}{l}162736 \\
56-68\end{array}$ & $\begin{array}{l}2492 \\
(1734 / 758)\end{array}$ & $\begin{array}{l}265 / 2258 \\
(11.7)\end{array}$ & $\begin{array}{l}75 / 2110 \\
(3.6)\end{array}$ & $\begin{array}{l}\text { No difference in MC or CM in } \\
\text { pregnancies exposed to TNF } \\
\text { inhibitors compared with controls }\end{array}$ & +++ & $2 b$ \\
\hline Rituximab & $\begin{array}{l}1 \text { register data } \\
20 \text { case reports/series }\end{array}$ & - & $\begin{array}{l}256 \\
(72 / 184)\end{array}$ & $\begin{array}{l}48 / 210 \\
(22.9)\end{array}$ & $\begin{array}{l}6 / 172 \\
(3.5)\end{array}$ & $\begin{array}{l}\text { Increased rate MC confounded } \\
\text { by disease indication, no } \\
\text { increased rate CMNo studies } \\
\text { with control group available }\end{array}$ & ++ & 4 \\
\hline Anakinra & $\begin{array}{l}1 \text { register data } \\
3 \text { case reports }\end{array}$ & - & $\begin{array}{l}40 \\
\text { (not reported) }\end{array}$ & $\begin{array}{l}4 / 40 \\
(10.0)\end{array}$ & $\begin{array}{l}2 / 34 \\
(5.9)\end{array}$ & $\begin{array}{l}\text { No increased rate MC or CM No } \\
\text { studies with control group } \\
\text { available }\end{array}$ & + & 4 \\
\hline Abatacept & $\begin{array}{l}1 \text { case series } \ddagger \\
1 \text { case report }\end{array}$ & - & $\begin{array}{l}152 \\
(94 / 58)\end{array}$ & $\begin{array}{l}40 / 151 \\
(26.5)\end{array}$ & $\begin{array}{l}7 / 87 \\
(8.0)\end{array}$ & $\begin{array}{l}\text { With concomitant MTX exposure } \\
\text { high rate MC and CMNo studies } \\
\text { with control group available }\end{array}$ & ++ & 4 \\
\hline Tocilizumab & $\begin{array}{l}1 \text { register data } \\
2 \text { case series } \\
(2 \text { abstracts) }\end{array}$ & - & $\begin{array}{l}218 \\
(180 / 38)\end{array}$ & $\begin{array}{l}47 / 218 \\
(21.6)\end{array}$ & $\begin{array}{l}5 / 128 \\
(3.9)\end{array}$ & $\begin{array}{l}\text { With concomitant MTX exposure } \\
\text { high rate } \mathrm{MC} \text {, no indication of an } \\
\text { increased rate } \mathrm{CM}\end{array}$ & ++ & 4 \\
\hline Ustekinumab & $\begin{array}{l}1 \text { register data } \\
4 \text { case reports/series } \\
\text { (1 abstract) }\end{array}$ & - & $\begin{array}{l}108 \\
(104 / 4)\end{array}$ & $\begin{array}{l}15 / 108 \\
(13.9)\end{array}$ & $\begin{array}{l}1 / 58 \\
(1.7)\end{array}$ & $\begin{array}{l}\text { No increased rate MC or CM No } \\
\text { studies with control group } \\
\text { available }\end{array}$ & ++ & 4 \\
\hline Belimumab & $\begin{array}{l}1 \text { register data } \\
1 \text { case series } \\
\text { (abstract) }\end{array}$ & - & $\begin{array}{l}153 \\
(152 / 1)\end{array}$ & $\begin{array}{l}41 / 153 \\
(26.8)\end{array}$ & $\begin{array}{l}7 / 71 \\
(9.9)\end{array}$ & $\begin{array}{l}\text { High rate } \mathrm{MC} \text { and } \mathrm{CM} \\
\text { Concomitant medication possible } \\
\text { confounderNo studies with } \\
\text { disease-matched controls } \\
\text { available }\end{array}$ & ++ & 4 \\
\hline
\end{tabular}

Strength of evidence based on previous consensus papers ${ }^{12}$ and new SLR and registry data.

${ }^{*}$ As the update publication did not include all non-biologic drugs, an additional search for the period 2006-2008 was performed for 10 drugs; NSAIDs, glucocorticoids, MTX, cyclophosphamide, sulfasalazine, antimalarials, azathioprine, colchicine, ciclosporin and IVIG.

†Total reported pregnancies for a given drug, where CM and/or MC are reported, and where the pregnancies have been exposed in the window of susceptibility for the reported outcome. $\ddagger$ Nominator represents exposed pregnancies with MC as outcome. Denominator represents the total number of exposed pregnancies where MC is reported.

$\S$ Nominator represents exposed pregnancies with CM in live births as outcome; mainly major CM but in some publications major and minor CM are not differentiated. Denominator represents the total number of exposed pregnancies resulting in live births.

१One cohort of 2295 pregnancies looks only at isolated clefts.

${ }^{* *}$ Nominator includes CM in elective terminations in addition to CM in live births. Denominator includes elective terminations with anomalies in addition to live births.

††Several publications report congenital malformations for women using different TNF inhibitors; nominator/denominator reflects numbers in which each TNF inhibitor is reported separately.

$\ddagger \ddagger$ Publication after 15 April (replacing earlier abstract).

IVIG, intravenous immunoglobulin; MTX, methotrexate; NSAID, non-steroidal anti-inflammatory drug; SLR, systematic literature review; TNF, tumour necrosis factor. 
agents with a long half-life, mainly biologics, with a safety margin five times the half-life.

For cyclophosphamide, ciclosporin, tacrolimus, glucocorticoids and IVIG the number of new publications shown in table 2 is lower than the number of citations retrieved in the literature search. The reason is that these drugs were often administered in combination therapies, and pregnancy outcomes in reports were given for a drug combination, not for each drug separately. The rate of miscarriage and congenital malformations can therefore be given only for studies reporting single drug exposure (table 2).

Several factors limit the completeness and reliability of pregnancy reports from pharmacovigilance centres and from pharmaceutical safety databases: spontaneously reported data often lack preciseness and completeness, and can be biased towards abnormal pregnancy outcomes, particularly in retrospectively collected cases. Information on concomitant medication is frequently absent. A major limitation of global safety databases is the high rate of pregnancies with unknown outcomes and high lost to follow-up rates up to $50 \%$. $^{69}$

\section{Lactation}

Studies on excretion of drugs into human breast milk are rare and mostly based on single-dose or short-term treatment, therefore grading of evidence for all drugs in table 3 is 'very low' (+) according to GRADE (see online supplementary table S3) and score 4-5 according to Oxford evidence rating (see online supplementary table S4). Even when transfer of a drug into milk has been investigated, children were often not breast fed, and the effect of the drug on the nursing infant remains unknown. References concerning lactation are available in online supplementary table S6.

\section{Follow-up of children}

Pregnancy exposures in any trimester might have the potential to impair organ function, alter the immune response or influence neurocognitive development in children. Studies published between 2006 and 2015 deal mainly with biologics, have a short follow-up time and show large gaps in reported outcomes (see online supplementary table S7). The available data for several biologics and immunosuppressives show no adverse effects on physical or neurocognitive development nor impaired immunocompetence in children during the 1 st year of life.

\section{Biologics}

Biologics are derivatives of IgG, and differ in structure, half-life and placental passage. The half-life ranges from 9 days to 23 days in complete IgG1 monoclonal antibodies and between 4 days and 13 days in Fc-fusion proteins (etanercept, abatacept). ${ }^{72}$ Active transport of biologics containing the Fc part of IgG1 is mediated by the fetal $\mathrm{Fc}$ receptor expressed in the placenta. $^{72}$ Transfer is thought to be very low during organogenesis, but to increase steadily after week 13 throughout pregnancy. Treatment of the mother with $\operatorname{IgG}$ antibodies expressing high affinity to the fetal Fc receptor after gestational week 30 can lead to fetal/ cord serum levels equal to or higher than maternal levels. ${ }^{61} \mathrm{IgG}$ has a prolonged half-life, up to 48 days $^{73}$ in the newborn; they typically disappear from the child's serum within the first 6 months of life.

The biologics with most pregnancy experience are the TNFi which have been in use for 15 years, including for indications outside rheumatology. For biologics approved $<5$ years ago, data on pregnancy and lactation are either sparse or completely absent (tables 2 and 3).

\section{Results of Delphi voting}

There was $90-100 \%$ consensus between experts of the task force on all statements on antirheumatic drugs during pregnancy (tables 4 and 5). Propositions regarding actual use of antirheumatic drugs during pregnancy and lactation in clinical practice received lower levels of agreement (tables 4 and 5). Disagreement between experts on clinical use during lactation was between $10-20 \%$ in general, and $25-31 \%$ for several biologics without data on transfer into breast milk (abatacept, tocilizumab, belimumab).

\section{DISCUSSION}

Available data from the literature and from registries show that a large proportion of medications can be taken by pregnant and lactating women with RD without causing measurable harm to the children. The SLR of the last decade strengthens the evidence for glucocorticoids, sulfasalazine, antimalarials, azathioprine, colchicine, ciclosporin, tacrolimus and IVIGs as being compatible with pregnancy and lactation (table 1). Major changes in regard to the 2006/2008 consensus paper are the following: The SLR and registry data support the use of TNFi in the first half of pregnancy. A study published after the completed Delphi voting showed a slight increase of birth defects at first trimester exposure to TNFi without any pattern of malformations. Given the absence of disease-matched controls the clinical significance of this finding is not yet clear. ${ }^{65}$

The difference in placental transfer related to molecule structure and half-life needs to be taken into account when selecting a TNFi for women of fertile age (table 5). As a consequence, infliximab and adalimumab may preferentially be stopped at 20 weeks, and etanercept at week $30-32$ of pregnancy. The safety of certolizumab in using it throughout pregnancy needs confirmation by extended published reports. Sound evidence for fetal/child safety is still lacking for certolizumab, golimumab, abatacept, tocilizumab, rituximab, belimumab and anakinra, but SLR and registry data do not suggest any evidence of harm from these agents when used before conception or in the first trimester (table 5).

The SLR and registry data showed only cyclophosphamide, MTX and MMF to be teratogenic necessitating their withdrawal before a planned pregnancy. For all other drugs labelled with a statement to discontinue them before or early in pregnancy, the reason is insufficient evidence that they are safe for the fetus, rather than evidence of harm.

Since $30-50 \%$ of pregnancies are unplanned, a major question is how to manage pregnancies that occur in women receiving therapy with teratogenic drugs. Some patients opt for immediate termination whereas others contemplate continuation of the pregnancy. Confirmation of pregnancy by a gynaecologist and determination of exact exposure dates for individual risk assessment and counselling are mandatory. A detailed ultrasound examination of the fetus should be offered to all patients who have an unintended pregnancy while taking a teratogenic drug. Macroscopic anomalies can be assessed by experienced fetal medicine specialists at the end of the first trimester and scans should be repeated at later stages of the second trimester. Other prenatal tests like amniocentesis or chorionic villous biopsy are usually not indicated after maternal drug exposure, but might be considered in patients with high risk of chromosomal problems or anomalies at ultrasound examination. 


\begin{tabular}{|c|c|c|c|c|c|c|}
\hline Drug & $\begin{array}{l}\text { Number } \\
\text { of cases* }\end{array}$ & $\begin{array}{l}\text { Drug detected in } \\
\text { breast milkt }\end{array}$ & $\begin{array}{l}\text { Weight-adjusted dose } \neq \text {, theurapeutic } \\
\text { infant dose or milk:plasma ratio }\end{array}$ & Infant serum level & $\begin{array}{l}\text { Reported side effects in } \\
\text { breastfed children }\end{array}$ & Comments \\
\hline $\begin{array}{l}\text { Non-selective COX } \\
\text { inhibitors (classical } \\
\text { NSAIDs) }\end{array}$ & 28 & $\begin{array}{l}\text { Not detected } \\
(n=20) \\
\text { Detected } \\
(n=14)\end{array}$ & $\begin{array}{l}\text { Weight-adjusted dose } \\
<0.1 \% \text { (minimal). } \\
\text { Dose }<0.1-5 \% \text { of therapeutic infant } \\
\text { dose }\end{array}$ & No data & $\begin{array}{l}\text { No adverse events } \\
(n=25)\end{array}$ & $\begin{array}{l}\text { Weak acids, with poor excretion in breast milk, but short half-life } \\
\text { agents preferred in neonatal period }\end{array}$ \\
\hline $\begin{array}{l}\text { Selective } \\
\text { cOX II } \\
\text { inhibitors }\end{array}$ & 25 & $\begin{array}{l}\text { Not detected } \\
(n=9) \\
\text { Detected } \\
(n=16)\end{array}$ & $\begin{array}{l}\text { Weight-adjusted dose } 0.1-1.2 \% \\
\text { (minimal) }\end{array}$ & $\begin{array}{l}\text { Not detected } \\
(\mathrm{n}=2)\end{array}$ & $\begin{array}{l}\text { No adverse events } \\
(\mathrm{n}=2)\end{array}$ & Data only for celecoxib \\
\hline Prednisone & 24 & Detected $(n=16)$ & $\begin{array}{l}\text { Weight-adjusted dose } \\
<1.5 \% \text { (minimal) if maternal dose } \leq 50 \\
\mathrm{mg}\end{array}$ & No data & $\begin{array}{l}\text { No adverse events } \\
(n=7)\end{array}$ & $\begin{array}{l}\text { Consider a } 4 \mathrm{~h} \text { delay before breast feeding after prednisone dose } \\
>50 \mathrm{mg}\end{array}$ \\
\hline Hydroxychloroquine & 18 & $\begin{array}{l}\text { Detected } \\
(n=10)\end{array}$ & $\begin{array}{l}\text { Weight-adjusted dose } \\
<2 \% \text { (minimal) }\end{array}$ & No data & $\begin{array}{l}\text { No adverse events } \\
(n=9)\end{array}$ & Long half-life \\
\hline Chloroquine & 61 & $\begin{array}{l}\text { Detected } \\
(n=61)\end{array}$ & $\begin{array}{l}\text { Weight-adjusted dose } \\
0.6-14 \% \\
\text { (minimal-moderate) }\end{array}$ & No data & No data & Long half-life \\
\hline Mepacrine (quinacrine) & 0 & No data & No data & No data & No data & \\
\hline $\begin{array}{l}\text { Sulfasalazine } \\
\text { (SSZ) }\end{array}$ & 29 & $\begin{array}{l}\text { Mesalamine not } \\
\text { detected } \\
(n=1) \\
\text { Mesalamine detected } \\
\text { low level }(n=3) \\
\text { Sulfapyridine detected } \\
(n=7)\end{array}$ & No data & $\begin{array}{l}\text { SSZ not detected } \\
(n=5) \\
\text { SSZ detected } \\
(n=2) \\
\text { Sulfapyridine } \leq 10 \% \text { of } \\
\text { maternal serum level } \\
(n=6)\end{array}$ & $\begin{array}{l}\text { No adverse events } \\
(n=6) \\
\text { Bloody diarrhoea } \\
(n=1)\end{array}$ & $\begin{array}{l}\text { SSZ consists of sulfapyridine and mesalamine (5-aminosalicylic } \\
\text { acid) which is considered to be the active component } \\
\text { Caution in premature children,G6PD deficit and } \\
\text { hyperbilirubinaemia }\end{array}$ \\
\hline Leflunomide & 0 & No data & No data & No data & No data & Long half-life \\
\hline Azathioprine§ & 72 & $\begin{array}{l}\text { Not detected } \\
(\mathrm{n}=14) \\
\text { Detected } \\
(\mathrm{n}=11)\end{array}$ & $\begin{array}{l}\text { Weight-adjusted dose } \\
<1 \% \text { (minimal). } \\
\text { Dose }<0.1 \% \text { of paediatric transplant } \\
\text { dose }\end{array}$ & $\begin{array}{l}\text { Not detected } \\
(n=16) \\
\text { Detected low level } \\
(n=1)\end{array}$ & $\begin{array}{l}\text { No adverse events } \\
(n=56) \\
\text { Neutropenia } \\
(n=1)\end{array}$ & Caution in thiopurine methyltransferase-deficient individuals \\
\hline Methotrexate & 3 & $\begin{array}{l}\text { Not detected } \\
(n=1) \\
\text { Detected low level }(n=2)\end{array}$ & No data & No data & $\begin{array}{l}\text { No adverse events } \\
(\mathrm{n}=1)\end{array}$ & $\begin{array}{l}\text { Limited excretion in breast milk due to mainly lipid insoluble form } \\
\text { at physiological pH }\end{array}$ \\
\hline Cyclophosphamide & 3 & $\begin{array}{l}\text { Detected } \\
(n=1)\end{array}$ & No data & No data & $\begin{array}{l}\text { Neutropenia and bone } \\
\text { marrow suppression } \\
(n=2)\end{array}$ & Alkylating agent; risk for side effects in breastfed child \\
\hline Ciclosporin & 76 & $\begin{array}{l}\text { Detected; variable titres } \\
(\mathrm{n}=19)\end{array}$ & $\begin{array}{l}\text { Weight-adjusted dose } \\
<2 \% \text { (minimal). } \\
\text { Dose }<2 \% \text { of paediatric transplant dose }\end{array}$ & $\begin{array}{l}\text { Not detected } \\
(n=12) \\
\text { Detected } \\
(n=2)\end{array}$ & $\begin{array}{l}\text { No adverse events } \\
(\mathrm{n}=68)\end{array}$ & LipophilicTitres in milk dependent on fat content in sampled milk \\
\hline Tacrolimus & 154 & $\begin{array}{l}\text { Detected; variable titres } \\
(\mathrm{n}=20)\end{array}$ & $\begin{array}{l}\text { Weight-adjusted dose }<0,5 \% \text { (minimal). } \\
\text { Dose }<0.5 \% \text { of paediatric transplant } \\
\text { dose }\end{array}$ & $\begin{array}{l}\text { Not detected } \\
(n=15) \\
\text { Detected, level declining with } \\
\text { time }(n=4)\end{array}$ & $\begin{array}{l}\text { No adverse events } \\
(\mathrm{n}=136)\end{array}$ & LipophilicTitres in milk dependent on fat content in sampled milk \\
\hline $\begin{array}{l}\text { Mycophenolate } \\
\text { mofetil }\end{array}$ & 7 & No data & No data & No data & $\begin{array}{l}\text { No adverse events } \\
(\mathrm{n}=7)\end{array}$ & Blocks purine synthesis and inhibits lymphocyte proliferation \\
\hline
\end{tabular}




\begin{tabular}{|c|c|c|c|c|c|c|}
\hline Drug & $\begin{array}{l}\text { Number } \\
\text { of cases* }\end{array}$ & $\begin{array}{l}\text { Drug detected in } \\
\text { breast milk } \dagger\end{array}$ & $\begin{array}{l}\text { Weight-adjusted dose } \ddagger \text {, theurapeutic } \\
\text { infant dose or milk:plasma ratio }\end{array}$ & Infant serum level & $\begin{array}{l}\text { Reported side effects in } \\
\text { breastfed children }\end{array}$ & Comments \\
\hline Colchicine & 154 & $\begin{array}{l}\text { Detected } \\
(\mathrm{n}=6)\end{array}$ & $\begin{array}{l}\text { Weight-adjusted dose } \\
<10 \% \text { (moderate) }\end{array}$ & $\begin{array}{l}\text { Not detected } \\
(n=1)\end{array}$ & $\begin{array}{l}\text { No adverse events } \\
(n=149)\end{array}$ & $\begin{array}{l}\text { Reconsider breast feeding if infant has diarrhoeaDue to drug } \\
\text { interaction, be aware of macrolide prescription in breastfed infants. }\end{array}$ \\
\hline IVIG & 149 & $\begin{array}{l}\text { IgG normal } \\
(\mathrm{n}=1) \\
\lg \text { high } \\
(\mathrm{n}=1)\end{array}$ & No data & No data & $\begin{array}{l}\text { No adverse events } \\
(\mathrm{n}=146) \\
\text { Transient rash } \\
(\mathrm{n}=1)\end{array}$ & Normal component of breast milk \\
\hline Tofacitinib & 0 & No data & No data & No data & No data & Low molecular weight might facilitate its passage into milk \\
\hline Infliximab§ & 25 & $\begin{array}{l}\text { Not detected } \\
(\mathrm{n}=5) \\
\text { Detected low level } \\
(\mathrm{n}=17)\end{array}$ & $\begin{array}{l}\text { Milk:plasma ratio } \\
1: 200 \\
\text { (minimal) }\end{array}$ & $\begin{array}{l}\text { Detected low level } \\
(\mathrm{n}=1) \\
\text { Not detected } \\
(\mathrm{n}=2)\end{array}$ & $\begin{array}{l}\text { No adverse events } \\
(\mathrm{n}=18)\end{array}$ & $\begin{array}{l}\text { Large protein molecule, } \\
\text { absorption unlikely due to low bioavailability }\end{array}$ \\
\hline Adalimumab§ & 10 & $\begin{array}{l}\text { Not detected } \\
(n=6) \\
\text { Detected low level }(n=3)\end{array}$ & $\begin{array}{l}\text { Milk:plasma ratio } \\
\text { 1:100-1: } 1000 \\
\text { (minimal) }\end{array}$ & $\begin{array}{l}\text { Not detected } \\
(\mathrm{n}=2)\end{array}$ & $\begin{array}{l}\text { No adverse events } \\
(n=7)\end{array}$ & $\begin{array}{l}\text { Large protein molecule, absorption unlikely due to low } \\
\text { bioavailability }\end{array}$ \\
\hline Golimumab§ & 0 & No data & No data & No data & No data & $\begin{array}{l}\text { Large protein molecule, absorption unlikely due to low } \\
\text { bioavailability }\end{array}$ \\
\hline Etanercept§ & 4 & $\begin{array}{l}\text { Detected low level } \\
(n=4)\end{array}$ & $\begin{array}{l}\text { Milk:plasma ratio } \\
1: 1000-1: 2000 \\
\text { (minimal) }\end{array}$ & $\begin{array}{l}\text { Detected at birth, but not } \\
\text { during breastfeeding period } \\
(\mathrm{n}=2)\end{array}$ & $\begin{array}{l}\text { No adverse events } \\
(n=1)\end{array}$ & $\begin{array}{l}\text { Large protein molecule, absorption unlikely due to low } \\
\text { bioavailability }\end{array}$ \\
\hline Certolizumab§ & 8 & $\begin{array}{l}\text { Not detected } \\
(\mathrm{n}=1)\end{array}$ & No data & $\begin{array}{l}\text { Not detected } \\
(\mathrm{n}=1)\end{array}$ & $\begin{array}{l}\text { No adverse events } \\
(\mathrm{n}=8)\end{array}$ & $\begin{array}{l}\text { Large protein molecule, absorption unlikely due to low } \\
\text { bioavailability }\end{array}$ \\
\hline Rituximab & 0 & No data & No data & No data & No data & $\begin{array}{l}\text { Large protein molecule, absorption unlikely due to low } \\
\text { bioavailability }\end{array}$ \\
\hline Anakinra & 1 & No data & No data & No data & $\begin{array}{l}\text { No adverse events } \\
(n=1)\end{array}$ & IL-1Ra is a normal component of human milk \\
\hline Ustekinumab & 0 & No data & No data & No data & No data & $\begin{array}{l}\text { Large protein molecule, absorption unlikely due to low } \\
\text { bioavailability }\end{array}$ \\
\hline Tocilizumab & 0 & No data & No data & No data & No data & $\begin{array}{l}\text { Large protein molecule, absorption unlikely due to low } \\
\text { bioavailability }\end{array}$ \\
\hline Abatacept & 0 & No data & No data & No data & No data & $\begin{array}{l}\text { Large protein molecule, absorption unlikely due to low } \\
\text { bioavailability }\end{array}$ \\
\hline Belimumab & 0 & No data & No data & No data & No data & $\begin{array}{l}\text { Large protein molecule, absorption unlikely due to low } \\
\text { bioavailability }\end{array}$ \\
\hline \multicolumn{7}{|c|}{$\begin{array}{l}\text { *Publications on breast feeding including maternal drug levels, infant drug levels or reports on side effects in breastfed children. Publications may include one, two or all three parameters. } \\
\text { TThe definition of detected or not detected agent in breast milk varies by method and chosen cut-off value. } \\
\text { fWeight-adjusted dose is child dose (mg/kg in child) relative to mother dose (mg/kg in mother): }<2 \%=\text { minimal, } 2-5 \%=10 w, 5-10 \%=\text { moderate, } 10-50 \%=h i g h .{ }^{70} \\
\text { \$Caution with the use of TNF inhibitors + thiopurines. These combinations might increase the risk of infant infections. } \\
\text { IVIG, intravenous immunoglobulin; TNF, tumour necrosis factor. }\end{array}$} \\
\hline
\end{tabular}




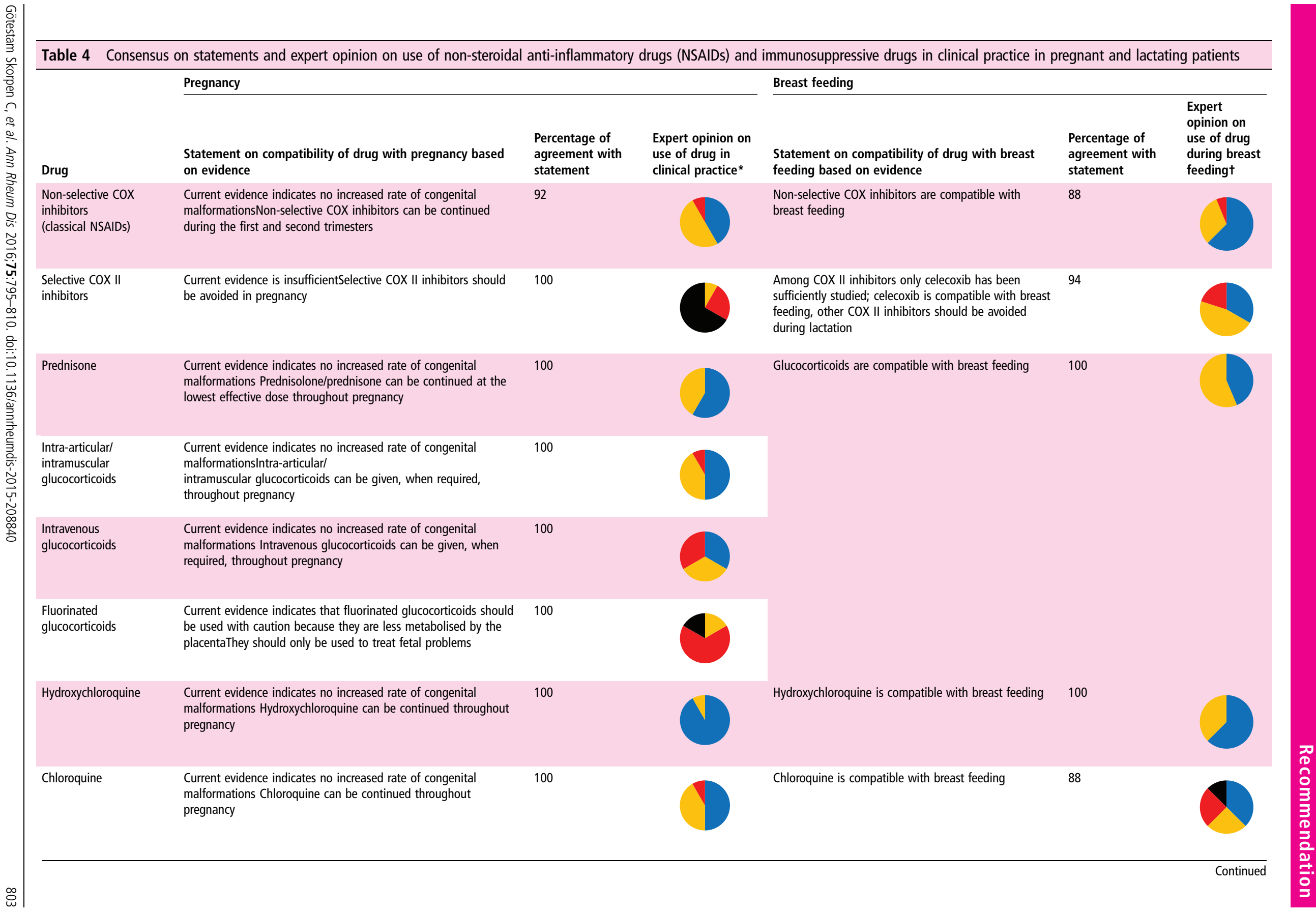


Statement on compatibility of drug with pregnancy based

Drug on evidence

Mepacrine (quinacrine) Current evidence is insufficientMepacrine should be avoided in pregnancy
Percentage of agreement with statement

100

Expert opinion on clinical practice

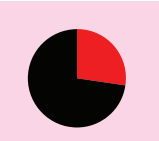

100

Current evidence indicates no increased rate of congenita malformations Sulfasalazine can be continued at doses up to $2 \mathrm{~g}$ day with concomitant folate supplementation throughout pregnancy

Leflunomide Current evidence is insufficientln a planned pregnancy, a washout 100 procedure should be completed before pregnancy Leflunomide should be avoided in pregnancy

100

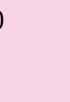

Azathioprine

Current evidence indicates no increased rate of congenital malformations Azathioprine can be continued at doses up to 2 $\mathrm{mg} / \mathrm{kg} /$ day throughout pregnancy

100

00

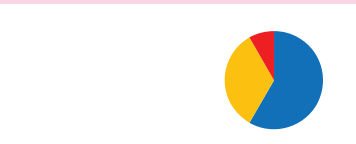

No data exist regarding leflunomide in breast milk feeding

$\begin{array}{ll}\text { Methotrexate } & \begin{array}{l}\text { Current evidence indicates an increased rate of congenital } \\ \text { malformationsIn a planned pregnancy, methotrexate should be } \\ \text { withdrawn 1-3 months before pregnancy }\end{array} \\ \text { Cyclophosphamide } \quad \begin{array}{l}\text { Current evidence indicates an increased rate of congenital } \\ \text { malformations Cyclophosphamide must be withdrawn before a } \\ \text { planned pregnancy }\end{array}\end{array}$

$\begin{array}{ll}\text { Cyclophosphamide } & \begin{array}{l}\text { The use of cyclophosphamide might be justified to treat } \\ \text { life-threatening conditions in the second and third trimesters }\end{array} \\ \text { Ciclosporin } & \begin{array}{l}\text { Current evidence indicates no increased rate of congenital } \\ \text { malformations Ciclosporin can be continued throughout } \\ \text { pregnancy at the lowest effective dose }\end{array}\end{array}$

Ciclosporin is compatible with breast feeding

malformations Ciclosporin can be continued throughout
94 therefore leflunomide should be avoided in breast

Azathioprine is compatible with breast feeding

Only small amounts of methotrexate appear in breast milk, but data are limited, therefore methotrexate should be avoided in breast feeding

There are limited data regarding cyclophosphamide in breast milk, therefore cyclophosphamide should be avoided in breast feeding

Expert

Expert

opinion on

use of drug $\begin{array}{ll}\text { agreement with } & \text { during breast } \\ \text { statement } & \text { feedingt }\end{array}$

100

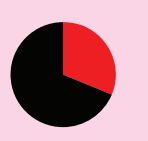

94

100

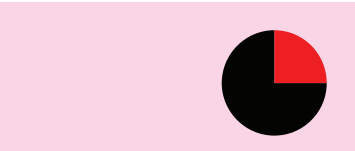

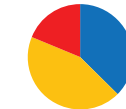

100

(2)

100

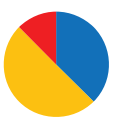

Continued 


\section{Breast feeding}

Pregnancy Statement on compatibility of drug with pregnancy based

Drug

Tacrolimus on evidence

Current evidence indicates no increased rate of congenital malformations Tacrolimus can be continued throughout pregnancy at the lowest effective dose using trough levels
Percentage of agreement with statement

100

100

Current evidence indicates an increased rate of congenital

Mycophenolate mofetil

(MMF)

1.5 months before pregnancy

Colchicine Current evidence indicates no increased rate of congenital

malformations Colchicine can be continued at doses up to $1 \mathrm{mg} /$

day throughout pregnancy

Intravenous Intravenous immunoglobulin can be used throughout pregnancy

immunoglobulin

100

\section{0}

$>$

Current evidence is insufficientln a planned pregnancy treatment with tofacitinib should be stopped 2 months before conception clinical practice ${ }^{\star}$

$\begin{array}{ll}\text { Tofacitinib } & \text { Current evidence is insufficientln a planned pregnancy treatment } \\ \text { with tofacitinib should be stopped } 2 \text { months before conception }\end{array}$

00

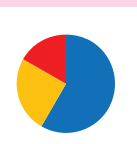

Expert opinion on use of drug in

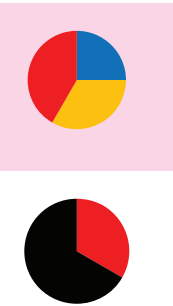

No data exist regarding MMF in breast milk, therefore

MMF should be avoided in breast feeding

Colchicine is compatible with breast feeding

100

Intravenous immunoglobulin is compatible with breast feeding

No data exist regarding tofacitinib in breast milk, therefore tofacitinib should be avoided in breast feeding

94

100
Expert

opinion on

use of drug

Percentage of

agreement with during breast

statement

feedingt

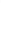

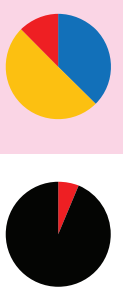

100

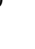

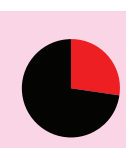

\section{${ }^{*}$ As an expert in the field.}

I would recommend the drug in the same way as if the patient was not pregnant.

I would only recommend the drug if I feared at least severe disease activity in its absence.

I would never recommend the drug in pregnancy.

tAs an expert in the field.

I would recommend the drug in the same way as if the patient did not breastfeed.

I would only recommend the drug if I feared at least severe disease activity in its absence.

I would never recommend the drug while the woman was breast feeding. 
Table 5 Consensus on statements and expert opinion on use of biologic drugs in clinical practice in pregnant and lactating patients

\begin{tabular}{|c|c|c|c|c|c|c|}
\hline \multirow[b]{2}{*}{ Drug } & \multicolumn{3}{|l|}{ Pregnancy } & \multicolumn{3}{|l|}{ Breast feeding } \\
\hline & $\begin{array}{l}\text { Statement on compatibility of drug with } \\
\text { pregnancy based on evidence }\end{array}$ & $\begin{array}{l}\text { Percentage of } \\
\text { agreement with } \\
\text { statement }\end{array}$ & $\begin{array}{l}\text { Expert opinion } \\
\text { on use of drug } \\
\text { in clinical } \\
\text { practice }(\%)^{*}\end{array}$ & $\begin{array}{l}\text { Statement on } \\
\text { compatibility of drug with } \\
\text { breast feeding based on } \\
\text { evidence }\end{array}$ & $\begin{array}{l}\text { Percentage of } \\
\text { agreement with } \\
\text { statement }\end{array}$ & $\begin{array}{l}\text { Expert opinion } \\
\text { on breast feeding } \\
\text { and medication } \\
(\%) \dagger\end{array}$ \\
\hline Infliximab & $\begin{array}{l}\text { Current evidence indicates no increased rate } \\
\text { of congenital malformations; infliximab can } \\
\text { be continued up to gestational week } 20 \text {; if } \\
\text { indicated, it can be used throughout } \\
\text { pregnancy }\end{array}$ & 100 & & $\begin{array}{l}\text { Infliximab is compatible } \\
\text { with breast feeding }\end{array}$ & 100 & \\
\hline Adalimumab & $\begin{array}{l}\text { Current evidence indicates no increased rate } \\
\text { of congenital malformations; adalimumab can } \\
\text { be continued up to gestational week 20; if } \\
\text { indicated, it can be used throughout } \\
\text { pregnancy }\end{array}$ & 100 & & $\begin{array}{l}\text { Adalimumab is compatible } \\
\text { with breast feeding }\end{array}$ & 100 & \\
\hline Golimumab & $\begin{array}{l}\text { Current evidence does not indicate an } \\
\text { increased rate of congenital malformations; } \\
\text { because of limited evidence, alternative } \\
\text { medications should be considered for } \\
\text { treatment throughout pregnancy }\end{array}$ & 100 & & $\begin{array}{l}\text { Golimumab is compatible } \\
\text { with breast feeding }\end{array}$ & 94 & \\
\hline Etanercept & $\begin{array}{l}\text { Current evidence indicates no increased rate } \\
\text { of congenital malformations; etanercept can } \\
\text { be continued up to gestational week } 30-32 \text {; } \\
\text { if indicated, it can be used throughout } \\
\text { pregnancy }\end{array}$ & 100 & & $\begin{array}{l}\text { Etanercept is compatible } \\
\text { with breast feeding }\end{array}$ & 100 & \\
\hline Certolizumab & $\begin{array}{l}\text { Current evidence indicates no increased rate } \\
\text { of congenital malformations; certolizumab } \\
\text { can be continued throughout pregnancy }\end{array}$ & 100 & & $\begin{array}{l}\text { Certolizumab is compatible } \\
\text { with breast feeding }\end{array}$ & 94 & \\
\hline Rituximab & $\begin{array}{l}\text { Current evidence indicates no increased rate } \\
\text { of congenital malformations; in exceptional } \\
\text { cases it can be used early in gestation; with } \\
\text { use at later stages of pregnancy clinicians } \\
\text { should be aware of the risk of B cell depletion } \\
\text { and other cytopenias in the neonate }\end{array}$ & 100 & & $\begin{array}{l}\text { No data exist regarding } \\
\text { rituximab in breast milk, } \\
\text { therefore rituximab should } \\
\text { be avoided in breast feeding }\end{array}$ & 80 & \\
\hline Anakinra & $\begin{array}{l}\text { Current evidence does not indicate an } \\
\text { increased rate of congenital malformations; } \\
\text { anakinra can be used before and during } \\
\text { pregnancy when there are no other well } \\
\text { studied options available for treatment }\end{array}$ & 100 & & $\begin{array}{l}\text { No data exist regarding } \\
\text { anakinra in breast milk, } \\
\text { therefore anakinra should } \\
\text { be avoided in breast feeding }\end{array}$ & 88 & \\
\hline Ustekinumab & $\begin{array}{l}\text { Current evidence does not indicate an } \\
\text { increased rate of congenital malformations; } \\
\text { because of limited evidence, alternative } \\
\text { medications should be considered for } \\
\text { treatment throughout pregnancy }\end{array}$ & 100 & & $\begin{array}{l}\text { No data exist regarding } \\
\text { ustekinumab in breast milk, } \\
\text { therefore ustekinumab } \\
\text { should be avoided in breast } \\
\text { feeding }\end{array}$ & 75 & \\
\hline Tocilizumab & $\begin{array}{l}\text { No statement can be made in regard to safety } \\
\text { during pregnancy due to scarce } \\
\text { documentation; treatment with tocilizumab is } \\
\text { therefore best avoided }\end{array}$ & 100 & & $\begin{array}{l}\text { No data exist regarding } \\
\text { tocilizumab in breast milk, } \\
\text { therefore tocilizumab should } \\
\text { be avoided in breast feeding }\end{array}$ & 69 & \\
\hline Abatacept & $\begin{array}{l}\text { No statement can be made in regard to safety } \\
\text { during pregnancy due to scarce } \\
\text { documentation; treatment with abatacept is } \\
\text { therefore best avoided }\end{array}$ & 94 & & $\begin{array}{l}\text { No data exist regarding } \\
\text { abatacept in breast milk, } \\
\text { therefore abatacept should } \\
\text { be avoided in breast feeding }\end{array}$ & 75 & \\
\hline Belimumab & $\begin{array}{l}\text { Current evidence does not indicate an } \\
\text { increased rate of congenital } \\
\text { malformations; because of limited evidence, } \\
\text { alternative medications should be considered } \\
\text { for treatment throughout pregnancy }\end{array}$ & 100 & & $\begin{array}{l}\text { No data exist regarding } \\
\text { belimumab in breast milk, } \\
\text { therefore belimumab should } \\
\text { be avoided in breast feeding }\end{array}$ & 82 & \\
\hline \multicolumn{7}{|c|}{$\begin{array}{l}\text { *As an expert in the field. } \\
\text { I would recommend the drug in the same way as if the patient was not pregnant. } \\
\text { I would only recommend the only recommend the drug if I feared at least severe disease activity in its absence. } \\
\text { I would never recommend the drug in pregnancy. }\end{array}$} \\
\hline
\end{tabular}


There was $90-100 \%$ agreement between experts of the task force with the statements on compatibility of antirheumatic drugs during pregnancy. However, much less agreement was achieved for the use of each drug in clinical practice. In the statements, emphasis was placed on congenital malformations whereas in the propositions for clinical use other considerations come into play including personal experience with a given drug, pharmacological properties of drugs, national preferences, availability of drugs in certain countries and legal issues. Statements on lactation were restricted to compatibility, and included no detailed advice on timing, short-term discontinuation of breast feeding or discarding milk on days of drug administration. As a consequence, great heterogeneity in regard to clinical practice among experts was observed (tables 4 and 5). This reflects the insufficient documentation in the field as well as the propensity to discourage patients in need of therapy from breast feeding although a flexible schedule would allow more women to breastfeed. Lactating mothers may have the opposite view, and would rather breast-feed than receive medications for active disease. Faced with a paucity of studies, pharmacological properties of drugs may act as a guide for decision to allow breast feeding even when there is scarce or no documentation (table 3). Non-ionised and lipophilic agents with a low molecular weight are the most likely to be transferred into breast milk. Highly protein-bound drugs or agents with high molecular weight are unlikely to cross extensively into breast milk. ${ }^{74}$ Term neonates, older or partially breastfed babies are usually at low risk for side effects of drugs in breast milk. Breast feeding is particularly important for premature and very low birthweight babies, however, no studies on this subgroup and the risks they may encounter by exposure to drugs in breast milk are available.

Studies on the long-term effects of drugs administered during pregnancy and/or breast feeding on child health and development are scarce, and often of low quality (see online supplementary table S7). The data available for azathioprine, ciclosporin and dexamethasone do not indicate immunosuppression in exposed children or raise special concern in regard to physical or neurological development (see online supplementary table S7). By contrast, biologics with extensive placental transfer achieving high serum levels in the child when administered after gestational week 30, might increase the risk of postnatal infection. Children exposed to biologics only before week 22 can receive vaccinations according to standard protocols including live vaccines. Children exposed at the late second and during the third trimester can follow vaccination programmes, but should not receive live vaccines in the first 6 months of life. When available, measurement of child serum levels of the biologic in question could guide the decision for or against a live vaccine.

The strengths of this study include the extensive SLR, inclusion of until now unpublished pharmacovigilance and registry data, and evaluation of data by experts from different specialties. Limitations of the study are the great variability in quality of reports in the literature and in registries. There is variety in disease indications and drug dosage. Assignment of an adverse pregnancy outcome to a particular drug can be influenced by confounders. Disease type, disease activity during pregnancy, extent of systemic inflammation and organ involvement, comorbidities, and concomitant drug therapy may all contribute to negative outcomes. When combinations of immunosuppressive and cytotoxic drugs are used defined pregnancy outcomes cannot be assigned to each of these classes of drugs separately. For recently approved biologics the adverse effect of concomitant use of MTX confounds the rate of miscarriages and of congenital malformations occurring after first trimester exposure in unintended pregnancies (table 5). In studies without carefully matched non-exposed control groups it is difficult to separate adverse drug effects from the above-mentioned confounders. Control groups are lacking in a majority of reports. The malformation rate is nearly always reported for live birth but does not include information on miscarriages or terminations. Therefore malformation rates are best derived from studies that include comparator groups of women with the same disease unexposed to the drug under consideration as well as non-exposed healthy pregnant women.

Treating a pregnant woman with RDs during pregnancy and lactation is a challenge since the well-being of two individuals, the mother and her child, has to be considered. Decisions on therapy during pregnancy and lactation have often been confounded by medical and legal concerns. ${ }^{75}$ The general cautious attitude to drug treatment during pregnancy and lactation has resulted in the withholding of necessary therapy, often at considerable risk for mother and child. ${ }^{75}$ Updating of knowledge in the field and dissemination of new insights is therefore of great importance in order to ensure implementation into daily practice and counselling. A publication based on SLR and available registry data is a first step that must be followed by dissemination of the new data through congresses, conferences, workshops and educational courses that include all types of healthcare providers (HCPs). Dissemination should target national societies of specialists in rheumatology, internal medicine, gynaecology and obstetrics, family medicine, paediatrics and pharmacology as well as national teratology information services. Disseminating the data through internet accessible websites would reach a large audience of the different HCPs who care for patients with RDs. Ideally the new insights should also be communicated to the patients at congresses, conferences and via national patient associations. Information needs on childbearing issues are great in women with RDs. ${ }^{76}$ There is a considerable gap in written material and educational resources that could meet this need. Development of evidence-based information on drugs in pregnancy/lactation, tailored for the lay public and accessible on the internet, would help patients make informed decisions.

\section{RECOMMENDATIONS FOR FUTURE RESEARCH}

Despite various international efforts, there is still limited evidence on the safety of a substantial number of drugs in pregnancy and lactation. The following are points for a research agenda:

1. All pharmaceutical companies should give academic institutions access to data on drug exposure during pregnancy and lactation from long-term extension studies of randomised trials and from registries. Independent assessment of the available data would be crucial.

2. Current initiatives for establishing pregnancy registers should be continued on a long-term and international basis. Specifically for the more recently licensed drugs, data collection should be intensified. Individual pregnancy registers are not likely to yield enough exposure and observation time to draw valid conclusions. Therefore, joint approaches among several countries which enable collaborative data analyses are recommended. EULAR could be an umbrella organisation for the harmonisation of approaches in establishing pregnancy registries.

3. Data collection should follow a protocol and be prospective, starting in early pregnancy or preferably when a pregnancy is planned and with high follow-up rates throughout 
pregnancy, lactation and during at least the 1st year of life of the child. Studies should include comparator groups of disease-matched women and their children unexposed to the drug under consideration as well as non-exposed healthy pregnant women.

4. The major gap in the documentation of transfer of drugs into human breast milk and the effect of drugs in breastfed children, including risk groups of premature and very low birthweight children, requires new and detailed studies.

\section{CONCLUSION}

Management of female patients with RDs during pregnancy and lactation requires weighing risks of withholding treatment from the mother against any risk to the fetus/child via exposure to drugs during pregnancy or breast feeding. Restrictions in use apply for the few proven teratogenic drugs and the large proportion of medications for which insufficient safety data for the fetus/child are available. The points to consider presented in this review show that, in spite of limitations, effective drug treatment of active $\mathrm{RD}$ is possible with reasonable safety for the fetus/child during pregnancy and lactation.

\section{Author affiliations}

${ }^{1}$ National Service for Pregnancy and Rheumatic Diseases, Department of Rheumatology, Trondheim University Hospital, Trondheim, Norway ${ }^{2}$ Department of Neuroscience, Norwegian University of Science and Technology (NTNU), Trondheim, Norway

${ }^{3}$ Department of Rheumatology, Ålesund Hospital, Ålesund, Norway

${ }^{4}$ Berlin Institute for Clinical Teratology and Drug Risk Assessment in Pregnancy, Charité-Universitätsmedizin Berlin, Berlin, Germany

${ }^{5}$ Department of Clinical and Experimental Science Rheumatology and Clinical Immunology Unit, Spedali Civili and University of Brescia, Brescia, Italy ${ }^{6}$ Department of Rheumatology, University Hospital of Düsseldorf, Duesseldorf, Germany

${ }^{7}$ Centre de Référence sur les Agents Tératogènes (CRAT), Groupe Hospitalier Universitaire Est, Hôpital Armand Trousseau, Paris, France

${ }^{8}$ Department of Pediatrics, University of California San Diego, La Jolla, USA

${ }^{9}$ Department of Rheumatology, University Hospital, Coimbra, Portugal

${ }^{10}$ Women's Health Academic Centre, St Thomas' Hospital, London, UK

${ }^{11}$ Department of Mother and Child, Hospital Luigi Sacco, University of Milano,

Milano, Italy

${ }^{12}$ Université Paris-Descartes, Paris, France

${ }^{13}$ Service de médecine interne, AP-HP, Hôpital Cochin, Centre de référence maladies auto-immunes et systémiques rares, Paris, France

${ }^{14}$ Department of Rheumatology, Erasmus MC, University Medical Center Rotterdam, Rotterdam, The Netherlands

${ }^{15}$ Department of Rheumatology, Immunology and Allergology, University Hospital of Bern, Bern, Switzerland

${ }^{16}$ Graham Hughes Lupus Research Laboratory, Division of Women's Health, King's

College London, The Rayne Institute, St Thomas' Hospital, London, UK

${ }^{17}$ Autoimmune Diseases Research Unit, Department of Internal Medicine, Biocruces Health Research Institute, University Hospital Cruces, University of the Basque Country, Bizkaia, Spain

${ }^{18}$ Epidemiology Unit, and Department for Rheumatology, German Rheumatism Research Centre, Charité University Medicine, Berlin, Germany

${ }^{19}$ Institute of Rheumatology, Praha, Czech Republic

${ }^{20}$ Research Laboratories and Academic Division of Clinical Rheumatology, Department of Internal Medicine, University of Genova, Genova, Italy

${ }^{21}$ EULAR Social Leagues Patients' representative, Leuven, Belgium

${ }^{22}$ EULAR Social Leagues Patients' representative, Zürich, Switzerland

Acknowledgements The authors thank Solveig Isabel Taylor; Medicine and Health Library, NTNU University Library Knowledge Center, St Olavs Hospital, Trondheim, Norway for help with the literature search; Ane S Simensen; The Norwegian Medicines Agency, Pharmacovigilance, Oslo, Norway for access to pregnancy reports; May Ching Soh; Division of Women's Health, Women's Health Academic Centre, King's College London, King's Health Partners, London, UK, for collecting data on lactation; Cecilia Nalli, Department of Clinical and Experimental Science Rheumatology and Clinical Immunology Unit, Spedali Civili and University of Brescia, Italy for collecting data on child outcome.

Contributors Each author has contributed to one or more of the following aspects of the manuscript-literature search, access to registry data, analysis and interpretation of data, drafting and revising the article. All authors approved the final version.

\section{Funding EULAR.}

Competing interests These are summarised below as remuneration for consultation and/or speaking engagements (' $R$ '), research funding (' $F$ ') or 'none'. AT—R: GSK, UCB, Pfizer, Abbott/Abbvie, IL; F: MSD, Pfizer, Roche, Abbott/Abbvie, BMS, Actelion; RF-B-R: Abbott/Abbvie, Chugai, GSK, MSD, Pfizer, Roche, SOBI, UCB; F:GSK, UCB; EE-R: Abbott/Abbvie; CC—F: AbbVie, Amgen, Apotex, Bristol Myers Squibb, Celgene, CSL, GSK, Janssen, Lilly, Pfizer, Roche-Genentech, Sandoz, Sanofi-Genzyme, Teva; JdS—R: Abbott/Abbvie, MSD, Pfizer, Roche, BIAL; CN-P—R LEO Pharma, Sanofi, UCB; IC-R: Bayer, Nestle, Pierre Fabre, Zambon; NC-Cnone; RD—F: UCB; FF—R: Mepha, Roche, UCB; MK—R: Inova Diagnostics, Medimmune/Astrazeneca,GSK, UCB, Menarini; F: Bayer; GR-I-none; AZ-R: AbbVie, BMS, MSD, Pfizer, Roche, Sanofi, UCB-F: AbbVie, BMS, GSK, Medac, MSD, Novartis, Pfizer, Roche, UCB; JV—R: UCB, Pfizer, MSD; MC—R: Actelion, BMS, Horizon, Abbvie, Novartis, Celltrion; MØ—R: Abbott/Abbvie, Mepha, MSD, New Bridge, Pfizer, Roche, UCB.

Provenance and peer review Not commissioned; externally peer reviewed.

\section{REFERENCES}

1 Ostensen M, Khamashta M, Lockshin M, et al. Anti-inflammatory and immunosuppressive drugs and reproduction. Arthritis Res Ther 2006;8:209.

2 Ostensen M, Lockshin M, Doria A, et al. Update on safety during pregnancy of biological agents and some immunosuppressive anti-rheumatic drugs. Rheumatology (Oxford) 2008;47(Suppl 3):iii28-31.

3 Dougados M, Betteridge N, Burmester GR, et al. EULAR standardised operating procedures for the elaboration, evaluation, dissemination, and implementation of recommendations endorsed by the EULAR standing committees. Ann Rheum Dis 2004;63:1172-6.

4 van der Heijde D, Aletaha D, Carmona L, et al. 2014 Update of the EULAR standardised operating procedures for EULAR-endorsed recommendations. Ann Rheum Dis 2015;74:8-13.

5 Ghogomu EA, Maxwell LJ, Buchbinder R, et al. Updated method guidelines for cochrane musculoskeletal group systematic reviews and metaanalyses. J Rheumatol 2014:41:194-205.

6 Hsu C-C, Sandford BA. The Delphi technique: making sense of consensus. Pract Asses Res Eval 2007:12:1-8.

7 Burns PB, Rohrich RJ, Chung KC. The levels of evidence and their role in evidence-based medicine. Plast Reconstr Surg 2011;128:305-10.

8 Goldet G, Howick J. Understanding GRADE: an introduction. J Evid Based Med 2013:6:50-4.

9 Jeremy H, lain C, Paul G. Explanation of the 2011 Oxford Centre for Evidence-Based Medicine (OCEBM) table of evidence. Background document. http:// www.cebm.net/index.aspx $? 0=5653$. (accessed Jan 2014).

10 Phillips B, Ball C, Sackett D, et al. Oxford Centre for Evidence-based Medicine-levels of evidence (March 2009). Centre for Evidence Based Medicine Web site. http:/ www.cebm.net/index.aspx?0=5653 (accessed Jan 2014).

11 Nezvalová-Henriksen K, Spigset O, Nordeng H. Effects of ibuprofen, diclofenac, naproxen, and piroxicam on the course of pregnancy and pregnancy outcome: a prospective cohort study. BJOG 2013:120:948-59.

12 Edwards DR, Aldridge T, Baird DD, et al. Periconceptional over-the-counter nonsteroidal anti-inflammatory drug exposure and risk for spontaneous abortion. Obstet Gynecol 2012;120:113-22.

13 van Gelder MM, Roeleveld N, Nordeng H. Exposure to non-steroidal anti-inflammatory drugs during pregnancy and the risk of selected birth defects: a prospective cohort study. PLOS ONE 2011;6:e22174.

14 Daniel $S$, Koren $G$, Lunenfeld $E$, et al. Fetal exposure to nonsteroidal anti-inflammatory drugs and spontaneous abortions. CMAJ 2014;186:E177-82.

15 Daniel S, Matok I, Gorodischer R, et al. Major malformations following exposure to nonsteroidal antiinflammatory drugs during the first trimester of pregnancy. J Rheumatol 2012;39:2163-9.

16 Viktil KK, Engeland A, Furu K. Outcomes after anti-rheumatic drug use before and during pregnancy: a cohort study among 150,000 pregnant women and expectant fathers. Scand J Rheumatol 2012;41:196-201.

17 Nakhai-Pour HR, Broy P, Sheehy O, et al. Use of nonaspirin nonsteroidal anti-inflammatory drugs during pregnancy and the risk of spontaneous abortion. CMAJ 2011;183:1713-20.

18 Al Arfaj AS, Khalil N. Pregnancy outcome in 396 pregnancies in patients with SLE in Saudi Arabia. Lupus 2010;19:1665-73.

19 Bay Bjørn AM, Ehrenstein V, Hundborg HH, et al. Use of corticosteroids in early pregnancy is not associated with risk of oral clefts and other congenital malformations in offspring. Am J Ther 2014;21:73-80.

20 Gomaa MF, Elkholy AG, El-Said MM, et al. Combined oral prednisolone and heparin versus heparin: the effect on peripheral NK cells and clinical outcome in patients with unexplained recurrent miscarriage. A double-blind placebo randomized controlled trial. Arch Gynecol Obstet 2014;290:757-62. 
21 Hviid A, Mølgaard-Nielsen D. Corticosteroid use during pregnancy and risk of orofacial clefts. CMAJ 2011;183:796-804.

22 Reddy D, Murphy SJ, Kane SV, et al. Relapses of inflammatory bowel disease during pregnancy: in-hospital management and birth outcomes. Am J Gastroenterol 2008;103:1203-9.

23 Tang AW, Alfirevic Z, Turner MA, et al. A feasibility trial of screening women with idiopathic recurrent miscarriage for high uterine natural killer cell density and randomizing to prednisolone or placebo when pregnant. Hum Reprod 2013;28:1743-52.

24 Diav-Citrin O, Blyakhman S, Shechtman S, et al. Pregnancy outcome following in utero exposure to hydroxychloroquine: a prospective comparative observational study. Reprod Toxicol 2013;39:58-62.

25 Clowse ME, Magder L, Witter F, et al. Hydroxychloroquine in lupus pregnancy. Arthritis Rheum 2006;54:3640-7.

$26 \mathrm{Koh} \mathrm{JH}, \mathrm{Ko} \mathrm{HS}$, Kwok SK, et al. Hydroxychloroquine and pregnancy on lupus flares in Korean patients with systemic lupus erythematosus. Lupus 2015;24:210-7.

27 Cooper WO, Cheetham TC, Li DK, et al. Brief report: risk of adverse fetal outcomes associated with immunosuppressive medications for chronic immune-mediated diseases in pregnancy. Lupus 2014;66:444-50.

28 Izmirly PM, Costedoat-Chalumeau N, Pisoni CN, et al. Maternal use of hydroxychloroquine is associated with a reduced risk of recurrent anti-SSA/ Ro-antibody-associated cardiac manifestations of neonatal lupus. Circulation 2012;126:76-82.

29 de Man YA, Hazes JM, van der Heide $\mathrm{H}$, et al. Association of higher rheumatoid arthritis disease activity during pregnancy with lower birth weight: results of a national prospective study. Arthritis Rheum 2009:60:3196-206.

30 Rahimi R, Nikfar S, Rezaie A, et al. Pregnancy outcome in women with inflammatory bowel disease following exposure to 5 -aminosalicylic acid drugs: a meta-analysis. Reprod Toxicol 2008;25:271-5

31 Nørgård B, Pedersen L, Christensen LA, et al. Therapeutic drug use in women with Crohn's disease and birth outcomes: a Danish nationwide cohort study. Am J Gastroenterol 2007;102:1406-13.

32 Chambers $C D$, Johnson DL, Robinson $L K$, et al. Birth outcomes in women who have taken leflunomide during pregnancy. Arthritis Rheum 2010;62:1494-503.

33 Karadag 0 , Kilic L, Erbil AA, et al. Pregnancy outcomes of rheumatic patients with pre/peri gestational leflunomide exposure.. Ann Rheum Dis 2013;72(Suppl 3): A896-7.

34 Alami Z, Cissoko H, Ahid S, et al. Pregnancy outcomes after maternal use of azathioprine: a French cohort Study.. Fundam Clin Pharmacol 2013:27:43.

35 Ban L, Tata LJ, Fiaschi L, et al. Limited risks of major congenital anomalies in children of mothers with IBD and effects of medications. Gastroenterology 2014;146:76-84

36 Casanova MJ, Chaparro M, Domènech $\mathrm{E}$, et al. Safety of thiopurines and anti-TNF- $\alpha$ drugs during pregnancy in patients with inflammatory bowel disease. Am J Gastroenterol 2013;108:433-40.

37 Cleary BJ, Kallen B. Early pregnancy azathioprine use and pregnancy outcomes. Birth Defects Res Part A Clin Mol Teratol 2009;85:647-54.

38 Coelho J, Beaugerie L, Colombel JF, et al. Pregnancy outcome in patients with inflammatory bowel disease treated with thiopurines: cohort from the CESAME Study. Gut 2011;60:198-203.

39 Goldstein LH, Dolinsky G, Greenberg R, et al. Pregnancy outcome of women exposed to azathioprine during pregnancy. Birth Defects Res Part A Clin Mol Teratol 2007;79:696-701.

40 Julsgaard M, Norgaard M, Hvas CL, et al. Influence of medical treatment, smoking and disease activity on pregnancy outcomes in Crohn's disease. Scand J Gastroenterol 2014;49:302-8.

41 Langagergaard V, Pedersen L, Gislum $\mathrm{M}$, et al. Birth outcome in women treated with azathioprine or mercaptopurine during pregnancy: a Danish nationwide cohort study. Aliment Pharmacol Ther 2007;25:73-81.

42 Shim L, Eslick GD, Simring AA, et al. The effects of azathioprine on birth outcomes in women with inflammatory bowel disease (IBD). J Crohns Colitis 2011;5: 234-8.

43 Martin MC, Barbero $\mathrm{P}$, Groisman B, et al. Methotrexate embryopathy after exposure to low weekly doses in early pregnancy. Reprod Toxicol 2014;43:26-9.

44 Weber-Schoendorfer C, Chambers C, Wacker E, et al. Pregnancy outcome after methotrexate treatment for rheumatic disease prior to or during early pregnancy: a prospective multicenter cohort study. Reprod Toxicol 2014;66:1101-10.

45 Cardonick E, Usmani A, Ghaffar S. Perinatal outcomes of a pregnancy complicated by cancer, including neonatal follow-up after in utero exposure to chemotherapy: results of an international registry. Am J Clin Oncol 2010;33:221-8.

46 Silva $\mathrm{CA}$, Hilario MO, Febronio MV, et al. Pregnancy outcome in juvenile systemic lupus erythematosus: a Brazilian multicenter cohort study. J Rheumatol 2008;35:1414-8.

47 Mohamed-Ahmed O, Nelson-Piercy C, Bramham K, et al. Pregnancy outcomes in liver and cardiothoracic transplant recipients: a UK national cohort study. PLOS ONE 2014;9:e89151.
48 Nulman I, Sgro M, Barrera M, et al. Long-term neurodevelopment of children exposed in utero to ciclosporin after maternal renal transplant. Paediatr Drugs 2010;12:113-22.

49 Perales-Puchalt A, Vila Vives JM, Lopez Montes J, et al. Pregnancy outcomes after kidney transplantation-immunosuppressive therapy comparison. J Matern Fetal Neonatal Med 2012;25:1363-6.

50 Hoeltzenbein M, Elefant E, Vial T, et al. Teratogenicity of mycophenolate confirmed in a prospective study of the European Network of Teratology Information Services. Am J Med Genet A 2012;158 A:588-96.

51 Ben-Chetrit E, Ben-Chetrit A, Berkun Y, et al. Pregnancy outcomes in women with familial Mediterranean fever receiving colchicine: is amniocentesis justified? Arthritis Care Res (Hoboken) 2010;62:143-8.

52 Diav-Citrin 0 , Shechtman S, Schwartz V, et al. Pregnancy outcome after in utero exposure to colchicine. Am J Obstet Gynecol 2010;203:144.e1-6.

53 Dendrinos S, Sakkas E, Makrakis E. Low-molecular-weight heparin versus intravenous immunoglobulin for recurrent abortion associated with antiphospholipid antibody syndrome. Int J Gynaecol Obstet 2009:104:223-5.

54 Heilmann L, Schorch M, Hahn T, et al. Pregnancy outcome in women with antiphospholipid antibodies: report on a retrospective study. Semin Thromb Hemost 2008;34:794-802.

55 Perricone R, De Carolis C, Kröegler B, et al. Intravenous immunoglobulin therapy in pregnant patients affected with systemic lupus erythematosus and recurrent spontaneous abortion. Rheumatology (Oxford) 2008;47:646-51.

56 Bortlik M, Machkova N, Duricova D, et al. Pregnancy and newborn outcome of mothers with inflammatory bowel diseases exposed to anti-TNF- $\alpha$ therapy during pregnancy: three-center study. Scand I Gastroenterol 2013;48:951-8.

57 Diav-Citrin 0, Otcheretianski-Volodarsky A, Shechtman S, et al. Pregnancy outcome following gestational exposure to TNF-alpha-inhibitors: a prospective, comparative, observational study. Reprod Toxicol 2014;43:78-84.

58 Giacuzzo S, Padovan M, Capucci R, et al. Pregnancy outcome of mothers with rheumatic diseases exposed to biological agent during pregnancy: a single-centre study. Ann Rheum Dis 2014;73(Suppl 2):414.

59 Kalari S, Granath F, Guo CY, et al. Pregnancy outcomes in women with rheumatologic conditions exposed to infliximab. Ann Rheum Dis 2014;73(Suppl 2):482-3.

60 Kelly $\mathrm{O}$, Hartery $\mathrm{K}$, Boland $\mathrm{K}$, et al. TNF alpha inhibitor use in pregnancy: Experience in a European cohort. J Crohn's Colitis 2014; 8:S204-S05.

61 Mahadevan U, Wolf DC, Dubinsky M, et al. Placental transfer of anti-tumor necrosis factor agents in pregnant patients with inflammatory bowel disease. Clin Gastroenterol Hepatol 2013;11:286-92.

62 Schnitzler F, Fidder $\mathrm{H}$, Ferrante $\mathrm{M}$, et al. Outcome of pregnancy in women with inflammatory bowel disease treated with antitumor necrosis factor therapy. Inflamm Bowel Dis 2011:17:1846-54.

63 Seirafi M, de Vroey, B, Amiot A, et al. Factors associated with pregnancy outcome in anti-TNF treated women with inflammatory bowel disease. Aliment Pharmacol Ther 2014;40:363-73.

64 Verstappen SM, King Y, Watson KD, et al. Anti-TNF therapies and pregnancy: outcome of 130 pregnancies in the British Society for Rheumatology Biologics Register. Ann Rheum Dis 2011;70:823-6.

65 Weber-Schoendorfer C, Oppermann M, Wacker E, et al. Pregnancy outcome after TNF- $\alpha$ inhibitor therapy during the first trimester: a prospective multicentre cohort study. Br I Clin Pharmacol 2015;80:727-39.

66 Zelinkova Z, van der Ent C, Bruin KF, et al. Effects of discontinuing anti-tumor necrosis factor therapy during pregnancy on the course of inflammatory bowel disease and neonatal exposure. Clin Gastroenterol Hepatol 2013;11:318-21.

67 Chambers $C$, Johnson D, Luo $Y$, et al. Pregnancy outcome in women treated with adalimumab for the treatment of rheumatoid arthritis: An update on the otis autoimmune diseases in pregnancy project.. Am J Gastroenterol 2014;109(Suppl): S638.

68 Johnson $\mathrm{D}$, Luo $\mathrm{Y}$, Jones $\mathrm{KL}$, et al. Pregnancy outcomes in women exposed to adalimumab: an update on the autoimmune diseases in pregnancy project.. Arthritis Rheum 2011;1(Suppl S10):1874.

69 Sinclair S, Cunnington M, Messenheimer J, et al. Advantages and problems with pregnancy registries: observations and surprises throughout the life of the International Lamotrigine Pregnancy Registry. Pharmacoepidemiol Drug Saf 2014;23:779-86

70 Nordeng H, Havnen GC, Spigset O. Drug use and breastfeeding. Tidsskr Nor Laegeforen 2012;132:1089-93.

71 Mahadevan U, Martin CF, Sandler RS, et al. Piano: A 1000 patient prospective registry of pregnancy outcomes in women with ibd exposed to immunomodulators and biologic therapy. Gastroenterology 2012;1:S149.

72 Suzuki T, Ishii-Watabe A, Tada M, et al. Importance of neonatal FcR in regulating the serum half-life of therapeutic proteins containing the Fc domain of human IgG1: a comparative study of the affinity of monoclonal antibodies and Fc-fusion proteins to human neonatal FcR. J Immunol 2010;184:1968-76. 
73 Sarvas H, Seppala I, Kurikka S, et al. Half-life of the maternal lgG1 allotype in infants. J Clin Immunol 1993;13:145-51.

74 Begg EJ, Atkinson HC, Duffull SB. Prospective evaluation of a model for the prediction of milk: plasma drug concentrations from physicochemical characteristics. Br J Clin Pharmacol 1992;33:501-5.
75 Dewulf L. Medicines in pregnancy —-women and children first? Time for a coalition to address a substantial patient need. Ther Innov Regul Sci 2013;47:528-32.

76 Cush JJ, Kavanaugh A. Editorial: pregnancy and rheumatoid arthritis—do not let the perfect become the enemy of the good. Curr Opin Rheumatol 2014;26:299-301. 